\title{
Penetapan Tarif Rasional Pelayanan Kesehatan RSUD Tenriawaru Kabupaten Bone
}

\section{Determination of Rational Tariffs for Health Service of General Hospital Tenriawaru Bone}

\author{
Darmawansyah $^{1 *}$, Muh.Yusri Abadi', Suci Rahmadani², Dian Marzuki', \\ Ryryn Suryaman ${ }^{3}$ \\ ${ }^{1}$ Jurusan Administrasi dan Kebijakan Kesehatan FKM Universitas Hasanuddin \\ ${ }^{2}$ Prodi S1 Administrasi Rumah Sakit STIKes Mega Rezky Makassar \\ ${ }^{3}$ Prodi S1 Administrasi Rumah Sakit STIKes Pelamonia Makassar \\ ('darmawansyah_akk@yahoo.com)
}

\begin{abstract}
ABSTRAK
Tarif pelayanan kesehatan RSUD Tenriawaru Kabupaten Bone masih berdasarkan Perda tahun 2012 sehingga perlu penelitian lebih dalam tentang tarif rasional. Penelitian bertujuan memperoleh informasi besarnya tarif rasional pelayanan beberapa pusat biaya di RSUD Tenriawaru Kabupaten Bone. Jenis penelitian observasional dimaksudkan untuk melakukan identifikasi terhadap semua karasteristik yang dipergunakan untuk menghitung total biaya (fixed cost) dan total biaya operasional tetap (semi variabel cost), dan total biaya operasional tidak tetap (variable cost) serta tarif setiap tindakan yang ada. Sampel penelitian semua transaksi yang berkaitan biaya tetap, biaya semi variabel dan biaya variabel pada pusat biaya. Pengumpulan data menggunakan teknik observasional dan dokumentasi. Analisis data menggunakan analisis biaya satuan dengan microsoft excell. Hasil penelitian menunjukkan tarif berdasarkan unit cost pada unit radiologi terbesar adalah Ultrasonografi Rp.280.000,-; fisioterapi terbesar adalah tindakan dengan menggunakan gymnastic pool Rp.250.000,-; tarif hemodialisis pada unit hemodialisa adalah Rp.1.000.000,-; NICU terbesar adalah resusitasi Rp.360.000,-; tarif berdasarkan unit cost dengan output normatif (BOR 80\%) per kelas perawatan sebagai berikut: Kelas VIP Utama Rp.420.000,-; Kelas VIP Rp.300.000,-; Kelas I Rp.240.000,-; Kelas II Rp.150.000,-; dan Kelas III Rp.95.000,-. Kesimpulan hasil perhitungan menghasilkan tarif rasional yang lebih tinggi dari tarif layanan saat ini.
\end{abstract}

Kata kunci : Tarif rasional, unit cost

\section{ABSTRACT}

Tariff of health service RSUD Tenriawaru Bone Regency is still based on by law in 2012 so that need more research about rational tariff. This study aims to obtain information on the rational tariff of several cost center services in RSUD Tenriawaru Bone Regency. This type of observational research is intended to identify all caracteristic used to calculate total cost (fixed cost) and total fixed operational cost (semi variable cost), and total operational cost is not fixed (variable cost) and tariff every action there. Sample research of all transactions related to fixed costs, semi-variable costs and variable costs at cost centers. Data collection using observational techniques and documentation. Data analysis using unit cost analysis with microsoft excell. The result of research shows that the health service tariff of RSUD Tenriawaru Bone Regency based on unit cost in the biggest radiology unit is USG (Ultrasound) Rp.280.000,-; the largest physiotherapy unit is action using gymnastic pool Rp.250.000,; hemodialysis rate on hemodialysis unit is Rp.1,000,000,-; largest NICU is resuscitation Rp.360.000,-; and unit cost of treatment classification with normative output (BOR 80\%) are as follows: Main VIP Class Rp.420.000,-; VIP Class Rp.300.000,-; Class I Rp.240.000,-; Class II Rp.150.000,-; and Class III Rp.95.000,--. The conclusion of the calculation results in a higher rational tariff than the current service rate.

Keywords : Rational tariff, unit cost

Copyright (C) 2018 Universitas Hasanuddin. This is an open access article under the CC BY-NC-SA license

(https://creativecommons.org/licenses/by-nc-sa/4.0/).

DOI : http://dx.doi.org/10.30597/mkmi.v14i2.3603 


\section{PENDAHULUAN}

Rumah Sakit sebagai organisasi publik diharapkan mampu memberikan pelayanan kesehatan yang bermutu kepada masyarakat. ${ }^{1}$ Namun, di satu sisi Rumah Sakit Umum Daerah (RSUD) Tenriawaru Kabupaten Bone dihadapkan pada masalah pembiayaan dalam arti alokasi anggaran yang tidak memadai sedangkan pendapatan dari penerimaan masih rendah dan tidak boleh digunakan secara langsung. Kondisi ini akan memberikan dampak serius bagi pelayanan kesehatan di rumah sakit karena sebagai organisasi yang beroperasi setiap hari, likuiditas keuangan merupakan hal utama dan dibutuhkan untuk menjalankan kegiatan operasionalnya. ${ }^{2}$

Sektor kesehatan memasuki abad ke-21 ditandai dengan adanya era globalisasi seperti meningkatnya jumlah penduduk, kemajuan ilmu dan teknologi di bidang kesehatan dan meningkatnya permintaan terhadap pelayanan kesehatan. ${ }^{3}$ Hal ini mengakibatkan biaya pelayanan kesehatan dari hari ke hari semakin tinggi. Di sisi lain, terjadinya inflasi menyebabkan semakin tingginya biaya obat-obatan, biaya komponen medik dan non medik pelayanan kesehatan yang canggih seperti AC, karpet, telepon, televisi dan lain-lainnya. ${ }^{4}$

Sebenarnya anggaran untuk pembiayaan kesehatan di Indonesia antara harapan dan kenyataan karena selama 50 tahun terakhir tidak melebihi angka 4,0\% (sekitar 3,0-4,0\%), sedangkan WHO menganjurkan minimal $5,0 \%$ dari dana anggaran pendapatan dan belanja negara. ${ }^{5}$ Salah satu kendala dalam mobilisasi dana adalah rendahnya tarif puskesmas dan rumah sakit sesuai Perda yang ditetapkan hanya berdasarkan pertimbangan politik dibanding pertimbangan ekonomi. ${ }^{6}$

Berdasarkan surat Keputusan Menteri Kesehatan RI No.582/ Menkes/SK/IV/1997, tanggal 11 Juni 1997 tentang Pola Tarif Rumah Sakit Pemerintah berdasarkan analisis biaya (unit cost) khususnya pada pasal 8 ayat 2, disebutkan bahwa unit cost rata-rata rawat inap dihitung melalui analisis biaya dengan metode distribusi ganda (double distribution) yaitu satu cara untuk menghitung satuan (unit cost) dengan mendistribusikan semua biaya yang terpakai di unit penunjang ke unit produksi (distribusi berganda).

Selama ini tarif tentang pelayanan kesehatan di Rumah Sakit Umum Daerah (RSUD) Ten- riawaru Kabupaten Bone masih berdasarkan Perda Nomor : 2012 Tanggal 5 Januari 2012 tentang tentang Tarif Pelayanan Kesehatan pada RSUD Kabupaten Bone, tarif yang diperlakukan pada Perda ini belum berdasarkan biaya satuan (unit cost based) dalam pelayanan kesehatan dan tanpa perhitungan yang cermat terhadap berbagai dimensi yang mempengaruhi tarif, bahkan belum ada penyesuaian tarif selama 5 tahun meskipun telah terjadi inflasi pelayanan kesehatan (obat, bahan habis pakai, dan lain-lain) sehingga peneliti tertarik untuk melakukan penelitian lebih dalam tentang biaya satuan per jenis tindakan.

Untuk mengatasi keadaan dan masalah yang berkembang atas kecenderungan permintaan biaya pelayanan kesehatan yang meningkat, rendahnya mobilisasi pembiayaan bukan saja dilaksanakan dan disesuaikan dengan prioritas yang berorientasi pada manfaat dan daya guna, akan tetapi perlu dipertimbangkan dengan kesesuaian dan kebijakan sistem administrasi dan sistem pembiayaan dengan analisis biaya satuan dan kemampuan untuk membayar. Oleh karena itu, perlu dilakukan penelitian untuk melihat tarif rasional per jenis tindakan pada pelayanan kesehatan di RSUD Tenriawaru Bone.

\section{BAHAN DAN METODE}

Jenis penelitian ini adalah penelitian observasional, yaitu observasi terhadap hasil transaksi yang ada di bagian keuangan. ${ }^{8}$ Penelitian ini dilaksanakan di RSUD Tenriawaru Kabupaten Bone pada bulan Januari s.d Maret 2017. Populasi dalam penelitian ini adalah semua hasil transaksi yang ada pada bagian radiologi, fisioterapi, hemodialisa, perina (NICU) dan rawat inap semua kelas perawatan di RSUD Tenriawaru Kabupaten Bone. Digunakan sampel total, yaitu semua transaksi yang berkaitan dengan biaya tetap, biaya semi variabel dan biaya variabel pada bagian radiologi, fisioterapi, hemodialisa, perina (NICU) dan rawat inap semua kelas perawatan di RSUD Tenriawaru Kabupaten Bone tahun 2016. Pengumpulan data primer menggunakan teknik observasional guna melihat data awal masing-masing unit cost pada bagian radiologi, fisioterapi, hemodialisa, perina (NICU) dan rawat inap semua kelas perawatan di RSUD Tenriawaru, intensitas dan efektivitas penggunaan alat, tarif dan pembagian tugas di RSUD 
Tenriawaru. Data Sekunder adalah data yang diperoleh langsung melalui laporan tahunan rumah sakit pada bagian keuangan, bagian rumah tangga, bagian administrasi tentang informasi biaya tahun 2016 di Rumah Sakit Umum Daerah Tenriawaru. Pengumpulan data sekunder menggunakan teknik dokumentasi guna mendata total cost dan pendapatan di Rumah Sakit Umum Daerah Tenriawaru tahun 2016.

Analisis biaya satuan dilakukan dengan spreadsheet program microsoft excell. Semua biaya yang akan dianalisis dan diklasifikasikan menjadi biaya tetap (fixed cost), biaya semi variabel (semi variabel cost) dan biaya variabel (variable cost). Biaya yang terdapat pada setiap unit penunjang didistribusikan ke setiap unit produktif, se- hingga biaya yang terdapat di unit produktif adalah biaya asli unit produksi itu sendiri ditambah dengan biaya pindahan dari unit penunjang. Perhitungan distribusi biaya asli menggunakan metode distribusi ganda (double distribution). Metode ini melakukan alokasi biaya dalam dua tahapan. Distribusi tahap I yaitu distribusi biaya asli dari pusat biaya penunjang lainnya ke pusat biaya produksi. Distribusi tahap II, mendistribusikan biaya hasil distribusi tahap I dari pusat biaya penunjang keseluruh pusat biaya produksi. Lalu dilanjutkan perhitungan RVU, RVU adalah nilai biaya satuan perjenis tindakan Perhitungan RVU didasarkan atas tarif sebelum dan sesudan perhitungan analisis unit cost. ${ }^{9}$ Data disajikan dalam bentuk tabel disertai dengan penjelasan.

Tabel 1. Asumsi Tarif Rasional Berdasarkan Unit Cost pada Instalasi Radiologi RSUD Tenriawaru

\begin{tabular}{|c|c|c|c|c|}
\hline \multirow{2}{*}{ No. } & \multirow{2}{*}{ Jenis Tindakan } & \multicolumn{3}{|c|}{ Unit Cost (Biaya Satuan) Rp. } \\
\hline & & Unit Cost & Asumsi Tarif & Usulan Berdasarkan Unit Cost \\
\hline 1 & Scapula & 155.328 & 217.459 & 200.000 \\
\hline 2 & Thorax & 141.883 & 198.636 & 200.000 \\
\hline 3 & Genu & 141.915 & 198.681 & 200.000 \\
\hline 4 & Cruris & 141.929 & 198.701 & 200.000 \\
\hline 5 & Ankle Joint & 141.915 & 198.681 & 200.000 \\
\hline 6 & Pedis & 141.915 & 198.681 & 200.000 \\
\hline 7 & Calcaneus & 141.915 & 198.681 & 200.000 \\
\hline 8 & Femur & 141.921 & 198.690 & 200.000 \\
\hline 9 & Mandibula & 144.113 & 201.758 & 200.000 \\
\hline 10 & Wrist Joint & 141.897 & 198.655 & 200.000 \\
\hline 11 & Antebrachi & 141.897 & 198.655 & 200.000 \\
\hline 12 & Cubiti & 141.897 & 198.655 & 200.000 \\
\hline 13 & Humerus & 141.897 & 198.655 & 200.000 \\
\hline 14 & Waters (Sinus Paranasal) & 144.675 & 202.546 & 200.000 \\
\hline 15 & Eisler & 142.116 & 198.962 & 200.000 \\
\hline 16 & Cranium & 141.941 & 198.717 & 200.000 \\
\hline 17 & Shoulder & 141.897 & 198.655 & 200.000 \\
\hline 18 & Shoulder Joint & 141.897 & 198.655 & 200.000 \\
\hline 19 & Thoraco Lumbal & 141.724 & 198.414 & 200.000 \\
\hline 20 & Clavicula & 143.363 & 200.708 & 200.000 \\
\hline 21 & Pelvis & 142.785 & 199.899 & 200.000 \\
\hline 22 & Maxilla & 143.444 & 200.821 & 200.000 \\
\hline 23 & Lumbo Sacral & 142.017 & 198.823 & 200.000 \\
\hline 24 & Servical & 152.511 & 213.516 & 215.000 \\
\hline 25 & Palangs & 141.863 & 198.608 & 200.000 \\
\hline 26 & Patella & 141.882 & 198.634 & 200.000 \\
\hline 27 & USG (Ultrasonografi) & 196.276 & 274.786 & 280.000 \\
\hline 28 & Manus & 141.863 & 198.608 & 200.000 \\
\hline 29 & Abdomen & 151.559 & 212.182 & 210.000 \\
\hline
\end{tabular}

Sumber : Data Sekunder, 2017 


\section{HASIL}

Besarnya biaya tetap dihitung dengan nilai biaya investasi tahunan (Annual Investment Cost=AIC) dari komponen biaya tetap pada rumah sakit yang meliputi biaya gedung, alat medis, alat non medis dan kendaraan..$^{10}$ Hasil analisis rumah sakit yang dikaji menunjukkan biaya tetap (fixed cost) pada RSUD Tenriawaru yang terbesar pada pusat biaya Kantor sebesar Rp.3.448.171.484,(24,4\%) dan biaya tetap (fixed cost) terkecil pada Hemodialisa yakni sebesar Rp.14.166.971,$(1,1 \%)$.

Semi variabel cost adalah semua biaya yang dikeluarkan oleh pihak rumah sakit yang besarnya tidak secara langsung tidak dipengaruhi oleh besarnya output produksi pada masing-masing pusat biaya, yang termasuk dalam kategori biaya ini adalah gaji pegawai dan pemeliharaan barang investasi yang pemakaiannya lebih dari satu tahun serta perjalanan dinas. ${ }^{11}$ Hasil analisis rumah sakit yang dikaji menunjukkan biaya semi variabel pada RSUD Tenriawaru terbanyak pada pusat biaya kantor yakni sebesar Rp.15.039.930.311,- (27,0\%) sedangkan yang terkecil pada pusat biaya Rawat Inap kelas II yakni sebanyak Rp.359.601.066,$(0,6 \%)$.

Biaya variabel adalah semua biaya yang dikeluarkan oleh pihak rumah sakit yang besarnya secara langsung dipengaruhi oleh besarnya output produksi. Biaya variabel meliputi biaya Bahan Habis Pakai (BHP) medis, dan non medis, biaya listrik, biaya air dan telepon. ${ }^{12}$ Hasil analisis pada rumah sakit yang dikaji menunjukkan biaya variabel pada RSUD Tenriawaru, biaya variabel

Tabel 2. Asumsi Tarif Rasional Berdasarkan Unit Cost pada Instalasi Fisioteari RSUD Tenriawaru

\begin{tabular}{|c|c|c|c|c|}
\hline \multirow[b]{2}{*}{ No. } & \multirow[b]{2}{*}{ Jenis Tindakan } & \multicolumn{3}{|c|}{ Unit Cost (Biaya Satuan) Rp. } \\
\hline & & Unit Cost & Asumsi Tarif & $\begin{array}{c}\text { Usulan Berdasarkan } \\
\text { Unit Cost }\end{array}$ \\
\hline 1 & Prosedur Pengukuran \& Proses FT & 20.861 & 29.206 & 30.000 \\
\hline 2 & Sinarinfra RED (IRR) & 21.839 & 30.575 & 30.000 \\
\hline 3 & Sinar Ultra Violet & 22.373 & 31.323 & 30.000 \\
\hline 4 & Diathermi & 26.414 & 36.979 & 35.000 \\
\hline 5 & Muscle Stimulasi & 32.809 & 45.933 & 45.000 \\
\hline 6 & Fibrator & 35.738 & 50.033 & 50.000 \\
\hline 7 & Parafin Bath & 46.966 & 65.752 & 65.000 \\
\hline 8 & Traksilumbal & 60.999 & 85.399 & 85.000 \\
\hline 9 & Traksi Cervical & 65.783 & 92.096 & 90.000 \\
\hline 10 & Terapi Latihan Manual & 41.010 & 57.414 & 60.000 \\
\hline 11 & Static Bicycle & 47.200 & 66.080 & 70.000 \\
\hline 12 & Powergyms & 32.737 & 45.832 & 45.000 \\
\hline 13 & Shoulder Will & 36.676 & 51.346 & 50.000 \\
\hline 14 & Paralel Bard & 66.707 & 93.389 & 90.000 \\
\hline 15 & Ultra Sound & 99.439 & 139.214 & 100.000 \\
\hline 16 & Tens & 37.711 & 52.796 & 50.000 \\
\hline 17 & Traid Mill & 68.127 & 95.377 & 95.000 \\
\hline 18 & Massase bayi & 59.858 & 83.801 & 85.000 \\
\hline 19 & Tindakan Menggunakan Gymnastic Pool & 176.701 & 247.381 & 250.000 \\
\hline
\end{tabular}

Sumber : Data Sekunder, 2017

Tabel 3. Asumsi Tarif Rasional Berdasarkan Unit Cost pada Bagian Hemodialisa RSUD Tenriawaru

\begin{tabular}{ccccc}
\hline \multirow{2}{*}{ No. } & Jenis Tindakan & \multicolumn{3}{c}{ Unit Cost (Biaya Satuan) Rp. } \\
\cline { 3 - 5 } & Unit Cost & Asumsi Tarif & $\begin{array}{c}\text { Usulan Berdasarkan } \\
\text { Unit Cost }\end{array}$ \\
\hline 1 & Hemodialisisi & 716.728 & 1.003 .420 & 1.000 .000 \\
\hline
\end{tabular}

Sumber : Data Sekunder, 2017 
Tabel 4. Asumsi Tarif Rasional Berdasarkan Unit Cost pada Perina (NICU) RSUD Tenriawaru

\begin{tabular}{clccc}
\hline & & \multicolumn{3}{c}{ Unit Cost (Biaya Satuan) Rp. } \\
\cline { 3 - 5 } No. & & Unit Cost Tindakan & Asumsi Tarif & $\begin{array}{c}\text { Usulan Berdasarkan } \\
\text { Unit Cost }\end{array}$ \\
\hline 1 & Resusitasi & 252.856 & 353.999 & 360.000 \\
2 & Transfusi Darah & 96.206 & 134.689 & 100.000 \\
3 & Pemasangan Infus & 42.193 & 59.070 & 60.000 \\
4 & Pemasangan OGT & 130.844 & 183.182 & 200.000 \\
5 & Mengambil Sampel Darah & 39.770 & 55.678 & 60.000 \\
6 & Suction & 21.166 & 29.633 & 30.000 \\
7 & Memasang Maag Slang & 32.645 & 45.702 & 45.000 \\
8 & Pemasangan C-PAP & 175.324 & 245.453 & 180.000 \\
9 & Intubasi (Baru) & 116.575 & 163.205 & 200.000 \\
10 & Terapi Sinar & 106.988 & 149.784 & 150.000 \\
11 & Perawatan Metode Kangguru & 127.719 & 178.806 & 180.000 \\
12 & Memandikan Bayi & 18.503 & 25.905 & 30.000 \\
13 & Memasang Monitor EKG & 19.631 & 27.483 & 35.000 \\
14 & Pemasangan Oksigen & 8.625 & 13.800 & 20.000 \\
15 & AFF OGT & 12.461 & 17.445 & 25.000 \\
16 & AFF Infus & 17.024 & 23.833 & 30.000 \\
17 & AFF Decompresi Lambung & 16.460 & 23.044 & 30.000 \\
18 & Ganti Verban Tali Pusat & 13.176 & 18.446 & 25.000 \\
\hline
\end{tabular}

Sumber : Data Sekunder, 2017

Tabel 5. Asumsi Tarif Perkelas Perawatan berdasarkan Nilai BOR Bagian Rawat Inap RSUD Tenriawaru

\begin{tabular}{lcccc}
\hline \multirow{2}{*}{ Kelas Perawatan } & \multicolumn{2}{c}{ Asumsi Tarif Berdasarkan Nilai BOR } & \multirow{2}{*}{ Tarif Rasional } \\
\cline { 2 - 4 } & Unit Cost & BOR Aktual & BOR Normatif (80\%) & \\
\hline Kelas VIP Utama & 426.625 & 420.736 & 341.300 & 420.000 \\
Kelas VIP & 214.656 & 302.552 & 171.724 & 300.000 \\
Kelas I & 415.274 & 236.186 & 332.219 & 240.000 \\
Kelas II & 672.540 & 154.162 & 538.032 & 150.000 \\
Kelas III & 125.068 & 94.477 & 100.054 & 95.000 \\
\hline
\end{tabular}

Sumber : Data Sekunder, 2017

terbanyak pada pusat biaya produksi Rawat Inap Kelas 3 yakni sebesar Rp.4.171.080.022,- (16,5\%) dan terkecil pada pusat biaya Instalasi Laundry yakni sebesar Rp.45.837.881,- $(0,2 \%)$.

Biaya total (total cost) adalah jumlah masingmasing biaya yang terdiri atas biaya tetap, biaya semi variabel dan biaya variabel sebelumya dilakukan proses Double Distribution. ${ }^{13}$ Perhitungan biaya ini untuk melihat besarnya biaya yang nyata dikeluarkan oleh masing-masing pusat biaya di rumah sakit. Biaya total terdiri atas Total Cost 1 (TC-1) $=\mathrm{FC}+\mathrm{SVC}+\mathrm{VC}$, Total Cost 2 $(\mathrm{TC}-2)=\mathrm{SVC}+\mathrm{VC}$ dan Total Cost 3 (TC-3) $=$ VC. ${ }^{9}$ Hasil analisis besarnya biaya total (TC) di rumah sakit yang dikaji menunjukkan biaya total (total cost) pada RSUD Tenriawaru. Untuk total biaya terbesar pada TC1 adalah Kantor yakni sebesar Rp.19.041.943.129,- pada TC2 yakni pusat biaya Kantor sebesar Rp.16.001.521.502,- dan TC3 yakni pusat biaya Rawat Inap Kelas III sebesar Rp.4.171.080.022,-. Untuk biaya terkecil pada semua total biaya adalah Laundry yakni masing-masing pada TC1 Rp.347.231.423,TC2 sebesar Rp.336.700.201,- dan TC3 sebesar Rp.45.837.881,-.

Biaya satuan (UC) berupa UC-1, UC-2 dan UC-3. Unit Cost-1 diperoleh dengan cara membagi total cost 1 (TC-1) dengan output masingmasing pusat biaya. ${ }^{14}$ Demikian hal-nya dengan unit cost-2 dan unit cost-3. Hasil analisis pada 
rumah sakit yang dikaji menunjukkan unit cost (UC) aktual pada pusat biaya produksi di RSUD Tenriawaru, UC-1, UC-2, dan UC-3 terbesar pada fisioterapi yakni masing-masing sebesar Rp.1.614.258,-; Rp.1.177.699,- dan UC-3 terbesar pada Rawat Inap Kelas VIP Utama yakni Rp.420.736,-; sedangkan yang terkecil pada UC1, UC-2, dan UC-3 adalah Perina (NICU) yakni masing-masing sebesar Rp.6.317,-; Rp.5.135,-; dan Rp.1.935,-.

Penetuan asumsi tarif per jenis tindakan di unit radiologi sebelumnya dilakukan perhitungan RVU dan unit cost per jenis tindakan. RVU adalah nilai pembobotan untuk masing-masing jenis tindakan yang merupakan nilai dari penjumlahan biaya bahan, gaji dan peralatan yang kemudian dibagi dengan konstanta. Setelah perhitungan RVU dan unit cost per jenis tindakan di unit radiologi diperoleh asumsi tarif (Tabel 1) bahwa jenis tindakan yang memiliki tarif tertinggi di Instalasi Radiologi yaitu tindakan USG (Ultrasonografi) yakni sebesar Rp.280.000,- dan yang terendah memiliki tarif sebesar Rp.200.000,- yakni tindakan Scapula, Thorax, Genu, Cruris, Ankle Joint, Pedis, Calcaneus, Femur, Mandibula, Wrist Joint, Antebrachi, Cubiti, Humerus, Waters (Sinus Paranasal), Eisler,Cranium, Shoulder, Shoulder Joint, Thoraco Lumbal, Clavicula, Pelvis, Maxilla, Lumbo Sacral, Palangs, Patella, dan tindakan Manus.

Tabel 2 menunjukkan bahwa jenis tindakan yang memiliki tarif tertinggi di instalasi fisioterapi berdasarkan unit cost yaitu tindakan tindakan dengan menggunakan gymnastic pool yakni sebesar Rp.250.000,-; dan yang terendah pada tindakan prosedur pengukuran dan proses FT, Sinar infra RED (IRR), dan Sinar Ultra Violet yakni masingmasing sebesar Rp. 30.000,-. Tabel 3 menunjukkan bahwa tarif jenis tindakan hemodialisis berdasarkan perhitungan RVU dan unit cost, yakni sebesar Rp.1.000.000,-.

Hasil analisis pada Tabel 4 diperoleh informasi bahwa jenis tindakan yang memiliki tarif tertinggi di Perina (NICU) berdasarkan unit cost yaitu tindakan resusitasi yakni sebesar Rp.360.000,-; dan yang terendah tindakan pemasangan oksigen yakni sebesar Rp.20.000,-. Tabel 5 diperoleh informasi bahwa pada bagian rawat inap didapatkan asumsi tarif berdasarkan nilai BOR Aktual masingmasing Kelas VIP Utama sebesar Rp.420.736,-;
Kelas VIP sebesar Rp.302.552,-; Kelas I sebesar Rp.236.186,-; Kelas II sebesar Rp.154.162,-; dan Kelas III sebesar Rp.94.477,-;.

\section{PEMBAHASAN}

Perhitungan biaya tetap merupakan perhitungan dalam waktu satu tahun (Annualized Investment Cost $=$ AIC) dengan memperhitungkan harga awal pembelian, masa pakai dan umur barang dengan menggunakan rumus. ${ }^{12}$ Hasil penelitian menunjukkan biaya tetap terbesar terdapat pada pusat Kantor, sebesar Rp.3.448.171.484,$(24,4 \%)$ dan biaya tetap (fixed cost) terkecil pada Hemodialisa yakni sebesar Rp. 14.166.971,$(1,1 \%)$. Rendahnya biaya tetap tersebut karena pusat biaya ini mempunyai AIC gedung yang rendah, apalagi pada pusat biaya ini tidak terdapat banyak alat medis. Dari seluruh kelas perawatan, Kelas VIP Utama memiliki biaya investasi tahunan paling besar dari total biaya investasi tahunan di ruang rawat inap Rumah Sakit Umum Daerah Tenriawaru Kabupaten Bone yang pada akhirnya akan berpengaruh pada perhitungan biaya satuan di rawat inap lainnya, karena menjadi komponen biaya satuan.

Hasil penelitian diperoleh informasi bahwa biaya gaji merupakan komponen terbesar dalam biaya semi variabel. Biaya gaji tersebut selain berupa gaji bulanan (THP), juga berupa insentif yang berasal dari Pemerintah Kabupaten Bone, seperti tunjangan khusus bagi tenaga dokter dan dana kesejahteraan yang diperuntukkan kepada semua pegawai, serta honorium bagi pegawai yang mengelola proyek atau program tertentu. Biaya semi variabel tertinggi untuk gaji pegawai terdapat pada pusat biaya Kantor yakni sebesar Rp.14.094.288.393,-; diikuti oleh Rawat Inap Kelas III yakni sebesar Rp. 5.756.301.094,-; dan biaya semi variabel untuk gaji paling rendah terdapat pada pusat biaya Rawat Inap kelas II yakni sebanyak Rp. 359.601.066,-; Hal ini disebabkan oleh kecilnya komponen biaya gaji dan jumlah pegawai. Biaya semi variabel tertinggi terdapat pada perawatan kelas III, hal ini disebabkan oleh besarnya komponen biaya gaji dan biaya pemeliharaan gedung, kendaraan, alat medis dan alat non medis.

Biaya variabel tertinggi terdapat pada pusat biaya Rawat Inap Kelas III yakni sebesar 
Rp.4.171.080.022,- (16,5\%) dan terkecil pada pusat biaya Instalasi Laundry yakni sebesar Rp.45.837.881,- $(0,2 \%)$. Tingginya biaya variabel pada pusat biaya instalasi Rawat Inap Kelas III sangat dimungkinkan karena besarnya biaya bahan makanan untuk pasien diakibatkan karena banyaknya jumlah pasien pada perawatan kelas III. Rendahnya biaya variabel pada pusat biaya Instalasi Laundry karena tidak ada pengeluaran untuk BHP medis.

Langkah awal untuk mengetahui besarnya nilai biaya satuan perjenis tindakan yakni dengan mencari nilai RVU yang merupakan perkalian antara bobot jenis tindakan dengan outputnya masing-masing pada tiap jenis tindakan. Besarnya nilai RVU sangat dipengaruhi oleh jumlah output dengan bobotnya. Dimana semakin tinggi nilai bobot atau semakin banyak outputnya, maka semakin tinggi nilai Relative Value Unit (RVU). Setelah nilai RVU pada semua jenis tindakan diperoleh maka biaya satuan (bagian cost) untuk setiap jenis tindakan dapat diperoleh dengan bantuan RVU. Besar dari unit cost per jenis tindakan sangat tergantung oleh dua hal yakni nilai RVU dan Total Cost.

Jenis tindakan yang memiliki tarif tertinggi di Instalasi Radiologi yaitu tindakan USG (Ultrasonografi) yakni sebesar Rp.280.000,- dan yang terendah memiliki tarif sebesar Rp.200.000,- yakni tindakan Scapula, Thorax, Genu, Cruris, Ankle Joint, Pedis, Calcaneus, Femur, Mandibula, Wrist Joint, Antebrachi, Cubiti, Humerus, Waters (Sinus Paranasal), Eisler, Cranium, Shoulder, Shoulder Joint, Thoraco Lumbal, Clavicula, Pelvis, Maxilla, Lumbo Sacral, Palangs, Patella, dan tindakan Manus. Jenis tindakan yang memiliki tarif tertinggi di Instalasi Fisioterapi berdasarkan unit cost yaitu tindakan Tindakan dengan Menggunakan gymnastic pool yakni sebesar Rp.250.000,dan yang terendah pada tindakan Prosedur Pengukuran \& Proses FT, Sinar infra RED (IRR), dan Sinar Ultra Violet yakni masing-masing sebesar Rp.30.000,-. Harga tindakan Hemodialisis yakni sebesar Rp.1.000.000,-. Jenis tindakan yang memiliki tarif tertinggi di Perina (NICU) berdasarkan unit cost yaitu tindakan Resusitasi yakni sebesar Rp.360.000,- dan yang terendah tindakan pemasangan oksigen yakni sebesar Rp.20.000,-.

Hal yang mempengaruhi besar kecilnya unit cost/asumsi tarif yang didapatkan dipengaruhi oleh penggunaan bahan, alat yang digunakan, besar gaji yang ditanggung dan besar/kecilnya output atau kasus yang ditangani. Dengan melihat besar biaya satuan perjenis tindakan khusus untuk TC III = VC dapat dijadikan acuan bagi rumah sakit untuk dapat menentukan kebijakan agar dapat berswadana dengan minimal dapat menutupi biaya operasional tidak tetap (variabel cost). Dalam mengatasi hal tersebut maka diharapkan pasien membayar sendiri kebutuhan obat dan peralatan sehingga dapat menekan pengeluaran.

Untuk dapat menurunkan besarnya unit cost pada bagian rawat inap dengan meningkatkan jumlah pasien dan hal ini dapat ditempuh dengan membuka instalasi perawatan untuk pasien umum dengan cara promosi yang lebih insentif dengan memberikan pengertian kepada masyarakat bahwa RSUD Tenriawaru Kabupaten Bone adalah rumah sakit umum untuk masyarakat. Sedangkan pada bagian atau pusat biaya yang memiliki unit cost yang tinggi maka guna menekan unit cost dapat dilakukan dengan meningkatkan jumlah output sehingga besarnya biaya tetap (fixed cost) dan bia- ya operasional tetap (semi variabel cost) dapat ditanggung bersama oleh pasien. Misalnya, pada umumnya alat untuk bagian Radiologi belum semua rumah sakit memilikinya sehingga upaya peningkatan jumlah pasien dapat ditempuh dengan melaksanakan pola kemitraan dengan penyedia pelayanan kesehatan yang belum memiliki fasilitas tersebut, misalnya dengan atau pelayanan kesehatan swasta yang ada. Di samping itu, perlunya efisiensi penggunaan BHP medis, non medis, air dan telepon pada bagian tersebut, guna memperkecil beban biaya yang harus ditangung pasien.

Tarif rumah sakit merupakan suatu harga pelayanan kesehatan yang diberikan yang ditetapkan oleh pemerintah daerah setempat, untuk suatu waktu periode tertentu. Dalam perdagangan umum, tarif atau harga berlaku menurut hukum pasar yang berfluktuasi dari satu waktu ke waktu lain. Dalam layanan kesehatan swasta tarif layanan juga dapat berfluktuasi, tetapi tidak secepat perubahan pada harga komoditi tertentu.

Fluktuasi harga jasa pelayanan kesehatan umumnya tidak berlangsung secepat fluktuasi harga barang konsumtif seperti pakaian atau mobil. Tarif rumah sakit ditetapkan oleh pemerintah 
yang umumnya tidak berfluktuasi dan cenderung berlaku untuk dua sampai lima tahun yang akibatnya tarif tersebut tidak dapat menutupi biaya untuk memproduksi jasa pelayanan rumah sakit. Pada saat pemerintah daerah mempunyai kemampuan keuangan yang cukup, hal ini tidak akan menjadi masalah tetapi dalam kondisi otonomi daerah maka jalan yang harus ditempuh untuk dapat meningkatkan mutu pelayanan kesehatan yaitu penetapan tarif rasional yang salah satunya harus berdasarkan unit cost per jenis tindakan (relative value unit). Penetapan tarif yang tidak sesuai dengan unit cost akan berdampak pada sulitnya rumah sakit memenuhi biaya operasionalnya sehingga subsidi pun dilakukan, seperti hasil penelitian perhitungan biaya satuan dengan metode distribusi ganda untuk pelayanan otopsi RSUD Dr. Soetomo Surabaya adalah Rp.1.369.587,- sedangkan tarif yang berlaku adalah Rp.661.000,- dengan CRR sebesar 48,26\% sehingga unit pelayanan otopsi merupakan unit cost center yang masih memerlukan subsidi untuk menjalankan pelayanannya. ${ }^{15}$

Dalam kondisinya rumah sakit memiliki banyak tindakan dalam bagian pelayanan yang belum masuk ke dalam tarif Perbup yang dijadikan dasar dalam tarif rumah sakit dan dalam kondisi lain bahwa terdapat tindakan dalam Perbup, tetapi belum memiliki output atau pasien belum memanfaatkan pelayanan tersebut. Sehingga tarif untuk beberapa tindakan yang tidak memiliki output dan unit cost, tarif yang ditampilkan adalah tarif pembanding dari rumah sakit lain yang setipe dengan RSUD Tenriawaru. Penelitian oleh Yusuf disimpulkan bahwa hasil dari perhitungan biaya ratarata rumah sakit umum per pasien adalah sebesar Rp.158.403,31,-, sedangkan tarif yang diberlakukan rumah sakit sesuai dengan peraturan daerah kabupaten Pinrang sebesar Rp.100.000,-. ${ }^{16}$

Pada bagian rawat inap diperoleh unit cost yang tertinggi pada UC-1 adalah pada Kelas VIP Utama sebesar Rp.1.291.766,- dan terendah pada Kelas III sebesar Rp.333.266,-. Pada UC-2 yang tertinggi adalah pada Kelas II sebesar Rp.1.093.026,- dan terendah pada Kelas III sebesar Rp.196.266,-. Pada UC-3 yang tertinggi adalah pada Kelas II sebesar Rp.672.540,- dan terendah pada Kelas III yakni sebesar Rp.125.068,- dengan selisih tarif perda pada Kelas III yakni (minus) Rp.89.068,-. Pada bagian rawat inap didapat- kan asumsi tarif berdasarkan nilai BOR Aktual masing-masing pada Kelas VIP Utama sebesar Rp.420.736,-, Kelas VIP sebesar Rp.302.552, Kelas I sebesar Rp.236.186,-, Kelas II sebesar Rp.154.162,- dan Kelas III sebesar Rp.94.477,-. Nilai unit cost khususnya pada unit cost 3 bervariasi misalnya pada Ruang Rawat Inap Kelas VIP lebih besar dari Perbup karena jumlah outputnya yang terbilang tinggi.

Tarif RSUD Tenriawaru Bone tersebut lebih tinggi dibandingkan hasil penelitian sebelumnya yang dilakukan di Rumah Sakit Umum Dr. Wahidin Sudiro Husodo Kota Mojokerto tahun 2013, dari perhitungan tarif pelayanan rawat inap dengan menggunakan metode activity based costing pada salah satu ruangan yang telah diteliti diketahui besaran tarif untuk Kelas I sebesar Rp.175.628,- sedangkan untuk Kelas II Rp. 97.412,-. ${ }^{17}$ Harga jasa rawat inap pada RSU Swasta Bethes tahun 2013 untuk Kelas VI Rp.132.500,-; Kelas I Rp.50.000,Kelas II Rp.30.000,-; Kelas III Rp.17.500,-. ${ }^{18}$ Asumsi tarif rasional RSU Anutapura Palu tahun 2013, Kelas VIP sebesar Rp.260.000,-/hari rawat, Kelas I sebesar Rp.155.000,-/hari rawat, Kelas II sebesar Rp.110.000,- per hari rawat dan Kelas III sebesar Rp.55.000,-/ hari rawat. ${ }^{19}$ Namun, dibandingkan dengan tarif RSUP Prof. DR. R. D. Kandou Manado lebih rendah kecuali kelas III, berdasarkan activity based costing untuk VIP sebesar Rp.592.250,-; Kelas I sebesar Rp.297.258,-; Kelas II sebesar Rp.199.649,- dan untuk Kelas III sebesar Rp.85.075,-.. ${ }^{20}$

\section{KESIMPULAN DAN SARAN}

Berdasarkan hasil pembahasan disimpulkan bahwa asumsi tarifpelayanan kesehatan berdasarkan unit cost di Rumah Sakit Umum Daerah Tenriawaru Kabupaten Bone adalah sebagai berikut: tarif tertinggi di Instalasi Radiologi yaitu tindakan USG (Ultrasonografi) yakni sebesar Rp.280.000,-. Tarif tertinggi di Instalasi Fisioterapi yaitu tindakan dengan menggunakan Gymnastic Pool yakni sebesar Rp.250.000,-. Tarif tindakan Hemodialisis yakni sebesar Rp.1.000.000,-. Tarif tertinggi di Perina (NICU) yaitu tindakan Resusitasi yakni sebesar Rp.360.000,-. Asumsi tarif berdasarkan unit cost dengan output normatif (BOR 80\%) per kelas perawatan yakni: Kelas VIP Utama Rp.420.000,, Kelas VIP Rp.300.000,-, Kelas I Rp.240.000, 
Kelas II Rp.150.000,-, dan Kelas III Rp.95.000,-Hasil perhitungan tarif lebih besar dari tarif yang digunakan saat ini. Rumah Sakit Umum Daerah Tenriawaru Kabupaten Bone sebaiknya melakukan pertimbangan mengenai penyesuaian tarif pelayanan kesehatan berdasarkan unit cost sehingga penentuan tarif dan estimasi laba yang diperoleh dapat lebih tepat.

\section{DAFTAR PUSTAKA}

1. Hasegawa M, Naito Y, Yamaguchi T, Wakabayashi H, Sudo A. Factors Contributing to Patient Satisfaction and Expectations following Computer-Assisted Total Knee Arthroplasty. J Knee Surg. 2017.

2. Razak A. Utilisasi, Permintaan Input dan Analisis Kebijakan Tarif Rawat Inap Rumah Sakit Umum di Sulawesi Selatan [Skripsi]. Makassar: Universitas Hasanuddin; 2004.

3. Sumilat ZTA. Penentuan Harga Pokok Penjualan Kamar Menggunakan Activity Based Costing pada RSU Pancaran Kasih GMIM. Jurnal Riset Ekonomi Manajemen, Bisnis dan Akuntansi. 2013;1(3).

4. Gani A. Demand for Health Service in Rural Area of Karanganyar Regency, Central Java, Indonesia, [thesis for Doctor of Public Health]. Baltimore, Maryland: John Hopkins University; 1996.

5. Trinantoro L. Aspek Strategis Manajemen Rumah Sakit : Antara Misi Sosial dan Tekanan Pasar. Yogyakarta: Penerbit Andi; 2005.

6. Thabrany d, , Faculty of Public Health University of Indonesia Colaborate with Dep. of Health Rep. of Indonesia - Bappenas. Comprehensive Review on JPKM to Develop a More Sustainable Insurance Scheme, Foundation for Advance of Public Health in Indonesia. Indonesia: Faculty of Public Health University of Indonesia colaborate with Dep. of Health Rep. of Indonesia; 2000.

7. Depkes. Keputusan Menteri Kesehatan RI No.582/ Menkes/SK/IV/1997. In: RI DK, editor. Jakarta: Departemen Kesehatan RI; 1997.

8. Ali F. Metodologi Penelitian Sosial Dalam Bidang Ilmu Administrasi. Ujung Pandang: CV. Bifaria; 1994.

9. Tunggal AW. Activity-Based Costing Untuk
Manufakturing dan Pemasaran. Jakarta: Harvarindo; 2000.

10. Raymond T. Hasil Analisis The Real Unit Cost Pelayanan Rumah Sakit, dalam Aspek Biaya Dampaknya Terhadap Kemandirian Rumah Sakit di era Otonomi Daerah. Yogyakarta: $\mathrm{Pu}-$ sat Manajemen Pelayanan Kesehatan Fakultas Kedokteran; 2001.

11. Budiman R. Implementasi Metode Activity-Based Costing System dalam Menentukan Besarnya Tarif Jasa Rawat Inap (Studi Kasus di RS XYZ). Jurnal ELKHA. 2013;4(2).

12. Maidin A. Ekonomi dan Pembiayaan Sektor Kesehatan. Makassar: Masgena Press; 2013.

13. Naki A. Analisis Biaya Satuan Pada Pasien Penyakit Dalam di Unit Rawat Inap di RSUD M.M.Dunda Limboto Kabupaten Gorontalo. Gorontalo: Universitas Gorontalo; 2005.

14. Tjiptoherijanto P, Soesetyo B. Ekonomi Kesehatan. Jakarta: Rineka Cipta; 2008.

15. Sulistyorini N, Moediarso B. Analisis Biaya Unit Pelayanan Otopsi dengan Metode Distribusi Ganda. Jurnal Kedokteran Forensik Indonesia. 2012;14(3).

16. Yusuf. Analisis Biaya Rata-Rata Rumah Sakit Terhadap Pasien Rawat Inap Kelas I dan Kaitannya dengan Standar Pelayanan Minimal (SPM) pada Rumah Sakit Umum Lasinrang Kabupaten Pinrang. 2003.

17. Kurniawan H, Widyawati D. Activity Based Costing dalam Penentuan Tarif Rawat Inap Rumah Sakit Umum. Jurnal Ilmu \& Riset Akuntansi. 2013;2(8).

18. B. Kaunang., S.K. Walandouw.Penerapan Metode Activity Based Costing System dalam Menentukan Besarnya Tarif Jasa Rawat Inap pada Rumah Sakit Umum Bethesda Kota Tomohon. Jurnal EMBA. 2015;3(1).

19. Nasri C, Darmawansyah, Asdar M. Tarif Rasional Berdasarkan Biaya Satuan (Unit Cost), Ability to Pay (ATP), Willinges to Pay (WTP) dan Forced to Pay (FTP) di Instalasi Rawat Inap Rumah Sakit Umum Anutapura Palu. Jurnal AKK. 2013;2(3).

20. Kula IJ. Metode Penerapan Biaya Rawat Inap Pada BLU RSUP Prof. Dr. R.D. Kandou Manado. Jurnal EMBA. 2013;1(3). 